\title{
1 Stable IgG-antibody levels in patients with mild SARS-CoV-2 infection
}

2 Thomas Åkerlund ${ }^{1 *}$, Katherina Zakikhany ${ }^{1}$, Charlotta Löfström ${ }^{2}$, Evelina Lindmark ${ }^{2}$, Henrik

3 Källberg $^{1}$, Ulla Elofsson ${ }^{2}$, Karin Cederbrant ${ }^{2}$, Erik Nygren $^{2}$, Anders Kallin $^{2}$, Nina Lagerqvist ${ }^{1}$,

4 Peter Nilsson ${ }^{3}$, Sophia Hober ${ }^{3}$, Anna Ridderstad Wollberg $^{2}$, Åsa Szekely Björndal ${ }^{1}$

$5 \quad{ }^{1}$ Public Health Agency of Sweden, Solna, Sweden

$6 \quad{ }^{2}$ RISE Research Institutes of Sweden, Borås, Sweden

$7 \quad{ }^{3}$ KTH Royal Institute of Technology, SciLifeLab, Stockholm, Sweden

9 *Corresponding author: Thomas Åkerlund, Department of Microbiology, Public Health Agency

10 of Sweden, Solna Sweden; email: thomas.akerlund@,folkhalsomyndigheten.se;

11 telephone; +46102052467

\section{Abstract}

14 More knowledge regarding persistence of antibody response to SARS-CoV-2 infections in the general population with mild symptoms is needed. We measured and compared levels of SARSCoV-2 spike- and nucleocapsid-specific IgG-antibodies in serum samples from 145 laboratoryconfirmed COVID-19 cases and 324 non-cases. The IgG-antibody levels against the spike protein in cases were stable over the time-period studied (14 to 256 days), while antibody levels against the nucleocapsid protein decreased over time. 
medRxiv preprint doi: https://doi.org/10.1101/2021.06.16.21258960; this version posted June 18, 2021. The copyright holder for this preprint (which was not certified by peer review) is the author/funder, who has granted medRxiv a license to display the preprint in perpetuity.

\section{Introduction}

The ongoing pandemic of the severe acute respiratory syndrome coronavirus 2 (SARS$\mathrm{CoV}-2$ ) and its associated respiratory disease, coronavirus disease 2019 (COVID-19), poses a major and unprecedented threat to global public health (1).

To date, serological tests are widely used to screen for antibodies made in response to a SARS-CoV-2 infection. The antibody responses to SARS-CoV-2 infection are directed against multiple viral antigens including the spike and the nucleocapsid protein (2). Antibodies against the spike-S1 protein, more specifically, the receptor-binding domain, have shown virus-neutralizing activity (3). especially with the ongoing roll out of general vaccination and immunity passports being discussed. Recent reports describe detectable IgG levels in approximately $80-90 \%$ of infected COVID-19 patients 4-8 months post infection (4-8). Several studies have included health-care workers with confirmed COVID-19 $(9,10)$, whose immune response may differ from that of the general population. In this context, there is a need for better understanding of antibody responses in the general population with largely mild symptoms.

Here, we characterize 469 serum samples collected from the general population in Sweden during October to December 2020. The samples were collected to establish a well-characterized national serum panel consisting of SARS-CoV-2 antibody-positive and negative samples for performance evaluation and quality assurance of serological tests. We assessed the antibody levels

41 against SARS-CoV-2 nucleocapsid and spike proteins in sera from 145 COVID-19 patients 14 to $42 \quad 256$ days after diagnosis. 
medRxiv preprint doi: https://doi.org/10.1101/2021.06.16.21258960; this version posted June 18, 2021. The copyright holder for this preprint (which was not certified by peer review) is the author/funder, who has granted medRxiv a license to display the preprint in perpetuity.

\section{Materials and methods}

44

45

46

47

\section{Recruitment of study participants}

Study participants were recruited from three Swedish Counties via internet-based advertisement. The advertisement was specifically directed towards persons who either had or had not contracted COVID-19 during 2020. A web-based questionnaire was used to collect information on basic demographics and anamnesis concerning COVID-19 (Figure S1). The purpose of the questionnaire was to pre-screen for candidates likely to donate either antibody-positive or negative serum samples, as well as to allow for weighing of samples regarding gender, age, county of residence (county 1-3) and symptoms of respiratory tract infection (RTI) other than COVID-19. Of 5444 persons completing the questionnaires, 780 individuals were selected for serum sampling according to the criteria mentioned above. Of these, 484 donated serum for the study (Table S1). Written consent was obtained from all study-participants. At the time of serum sampling, vaccination campaigns had not yet started in Sweden.

\section{Serum sampling}

Venous blood (5-40 mL) was collected into Serum Sampling Tubes (SST BD Vacutainer) on county level and transported at ambient temperature to regional laboratories for centrifugation and isolation of serum. Serum sample aliquots were subsequently shipped to RISE Research Institutes of Sweden for further analysis.

\section{Case definitions}

Patient-cases were defined as study participants with a laboratory-confirmed SARS-CoV2 infection, i.e. with positive real-time reverse transcription PCR test (rRT-PCR), as reported in 
medRxiv preprint doi: https://doi.org/10.1101/2021.06.16.21258960; this version posted June 18, 2021. The copyright holder for this preprint (which was not certified by peer review) is the author/funder, who has granted medRxiv a license to display the preprint in perpetuity.

All rights reserved. No reuse allowed without permission.

64 the national Swedish SmiNet database (electronic monitoring system for notifications received in

65 accordance with the Communicable Diseases Act). For data analysis, dates for rRT-PCR-

66 diagnostics were primarily used, and if missing, disease notification dates were used.

67 Non-cases were defined as study participants with no reported laboratory-confirmed

68 SARS-CoV-2 infection (i.e. rRT-PCR test) as per recording in the SmiNet database up to the

69 serum sampling date.

Of 484 participants, 15 were excluded due to incomplete personal identification number,

71 missing serum samples, or if serum sampling had occurred within 14 days of disease onset.

One follow-up search in the SmiNet database for possible reinfections and/or new

73 infections for the cohort was performed on April 12, 2021.

\section{Antibody testing}

Sera were tested for the presence of IgG antibodies against SARS-CoV-2 at the Science

76 for Life Laboratory (SciLifeLab) in Solna, Sweden. Testing was performed using a semi-

77 quantitative multiplex bead-based serologic assay for detection of antibodies to two different

78 SARS-CoV-2 viral proteins, the C-terminal part of the nucleocapsid protein (NCP-C) and the

79 soluble spike glycoprotein (spike-foldon) (11). The sensitivity and specificity of the method was

80 specified as 99.7\% (95\% CI: 98.3-100\%) and 100\% (95\% CI: 99.8-100\%), respectively. Results

81 were obtained as fluorescence intensity in a FlexMap3D instrument (Luminex) and are here given

82 as arbitrary units (AU). Each run included twelve negative and four positive reference samples.

83 Cut-off was determined as the "mean $+6 \times \mathrm{SD}$ " of the twelve negative reference samples.

84 Seropositivity was defined as AU above the cut-off for both the nucleocapsid and spike protein.

85 The median AU value of the four positive samples was used for normalization between assays. 
medRxiv preprint doi: https://doi.org/10.1101/2021.06.16.21258960; this version posted June 18, 2021. The copyright holder for this preprint (which was not certified by peer review) is the author/funder, who has granted medRxiv a license to display the preprint in perpetuity.

All rights reserved. No reuse allowed without permission.

86 Three separate runs were performed, and the values were normalized against the run with the

87 largest number of samples. Testing was performed blinded, i.e. without disclosing any case

88 information of the samples.

\section{$89 \quad$ Statistical analysis}

To compare groups, i.e. cases vs. non-cases and cases only regarding severity (hospital vs.

91 ill at home) we performed pairwise t-test, Mann-Whitney U-test and ANCOVA. ANCOVA was

92 used to allow for correction of variability of gender, age and time between diagnosis (positive rRT-

93 PCR) and serum sampling. We only present P-values based on ANCOVA for group comparisons.

94 Furthermore, we estimated Pearsons correlation coefficient for the log of nucleocapsid and spike

95 antibody levels (AU) in cases. R version 3.6.2 was used for all analysis.

Ethical approval and financing

Ethical approval for this study was obtained from the Swedish Ethical Review Board: Dnr 
medRxiv preprint doi: https://doi.org/10.1101/2021.06.16.21258960; this version posted June 18, 2021. The copyright holder for this preprint (which was not certified by peer review) is the author/funder, who has granted medRxiv a license to display the preprint in perpetuity.

\section{Results}

\section{Demographics and clinical characteristics}

Serum samples from the 469 included study participants were collected between October

19-patients in the national registry system (SmiNet) and subsequently classified as patient-cases.

All patient-cases had sampling/diagnosis dates between March 6 and November 9, 2020 and had

19 diagnosis in the follow-up search on April 12, 2021.

Most patient-cases, $85 \%$, self-reported severity of illness as mild (Table 1) and symptoms that they had or suspected to have had contracted COVID-19 during 2020 (Table 1).

\section{IgG antibody levels in patient-cases and non-cases}

About $95 \%$ of patient-cases (137/145) were classified as seropositive, i.e. serum samples

119 (Table 2). Of the eight seronegative samples, four had antibodies against either spike or nucleocapsid and another four had no detectable antibodies against any of the included antigens.

121 The four non-reactive samples showed background levels in the same range as the majority of non-

122 case samples for the spike protein (Figure 1) and the fluorescence intensity levels showed a 123 discontinuous distribution (Figure 2). These four non-reactive samples were thus considered as 
medRxiv preprint doi: https://doi.org/10.1101/2021.06.16.21258960; this version posted June 18, 2021. The copyright holder for this preprint (which was not certified by peer review) is the author/funder, who has granted medRxiv a license to display the preprint in perpetuity.

All rights reserved. No reuse allowed without permission.

124 outliers and were excluded for the analyses. There were no significant differences in seropositivity

125 or antibody levels between age groups (Figure S2) or gender (not shown).

Fourteen non-cases (4\%) were classified as seropositive (Table 2). Among the 55 non-

127 cases that self-reported to have contracted COVID-19 during 2020, 10 tested seropositive (18\%)

128 and 45 tested negative (82\%). Geographically, County 1 had a higher proportion of seropositive

129 samples among non-cases than the other two counties (Table S1).

IgG antibody levels and severity of disease

Among patient-cases, antibody levels against the spike protein were higher in patients with

132 moderate to severe disease compared to patients with mild disease $(\mathrm{P}=0.004$, ANCOVA, Figure

133 3). A similar association was found for antibody levels against the nucleocapsid protein $(\mathrm{P}=0.007$,

134 ANCOVA).

$135 \quad$ IgG antibody levels in patient-cases in relation to time after diagnosis

For 141 patient-cases (excluding the four outliers), disease notification dates were recorded

137 between March 6 and November 9, 2020, with a majority (30\%) recorded in June, followed by

$13817 \%$ in May and October, respectively. The median time between disease notification date and

139 serum sampling was 156 days (range 15-256 days). Four samples were collected 15-20 days after

140 disease notification and 137 samples between 21-256 days. For the 4/141 samples that were

141 classified as seronegative, three samples tested positive for antibodies against the spike protein

142 and one sample tested positive for antibodies against the nucleocapsid protein. These samples were

143 collected at day 160, 176, 207, and 232 after diagnosis. 
medRxiv preprint doi: https://doi.org/10.1101/2021.06.16.21258960; this version posted June 18, 2021. The copyright holder for this preprint (which was not certified by peer review) is the author/funder, who has granted medRxiv a license to display the preprint in perpetuity.

All rights reserved. No reuse allowed without permission.

There were no significant differences in IgG antibody levels against the spike protein over

145

146

147

148 highlights the need for careful interpretation of serological non-responders as well as adherence to time (Figure 4, $\mathrm{R}=-0.059, \mathrm{P}=0.49$ ). Conversely, antibody levels against the nucleocapsid protein were lower for patients diagnosed earlier during spring compared to those in the autumn $(\mathrm{R}=$ $0.19 ; \mathrm{P}=0.02)$

\section{Discussion}

We describe the IgG antibody levels in 145 serum samples from patients with a confirmed COVID-19 diagnosis between March and November 2020 in Sweden. The 145 patient samples were part of 469 serum samples, collected with the purpose to establish a national serum panel for validation and quality assessment of serological assays.

Our data showed that $95 \%$ of patient-cases seroconverted after a laboratory-confirmed infection with SARS-CoV-2, and there was no difference with respect to age group or gender. Early studies reported 15-90\% seroconversion rate in COVID-19 patients, with lower rates among asymptomatic patients $(12,13)$. One explanation for the varying results are performance differences among serological methods (14-16). Despite the high performance of the method used in this study, eight samples were classified as seronegative. Whereas four patient-cases had detectable IgG levels against one of the two antigens, the remaining four were distinguished by having background fluorescence levels similar to those of the negative controls. Although not conclusive, these outliers most likely represent false positive rRT-PCR diagnostic results. Large scale diagnostic testing in low prevalence settings increases the risk for false positives (17), and the case definition of putative reinfections (18). 
medRxiv preprint doi: https://doi.org/10.1101/2021.06.16.21258960; this version posted June 18, 2021. The copyright holder for this preprint (which was not certified by peer review) is the author/funder, who has granted medRxiv a license to display the preprint in perpetuity.

All rights reserved. No reuse allowed without permission.

The levels of IgG antibodies against the spike and nucleocapsid proteins were higher in

166

167

168

169

170

171

172

173

174

175

176

177

patients with moderate to severe disease than in patients with mild disease. Reports have shown various results regarding the antibody levels in patients with severe and mild disease $(16,19,20)$, which may be due to timing of antibody response in relation to the phase of the infection (21).

One strength of this study is that samples were collected from the general population, covering patients with mostly mild disease. The results indicate that the antibody levels, particularly against the spike protein, remain at detectable levels for more than eight months. This is in agreement with other studies showing a sustained antibody response, e.g. 6-9 months after infection $(4,5,7,22-24)$. Neutralizing antibodies are evidently important for protection against disease (25), and protection over longer time-periods depends on the evolution of memory B cells (26). In this context, it is interesting to note that only one episode of COVID-19 per case was registered between March 6, 2020 and April 12, 2021, while 9\% of the non-cases were diagnosed with COVID-19 during the 3.5 months that passed after serum sampling.

Due to the unknown number of undiagnosed SARS-CoV-2 infections in the population, one challenge of our approach was to collect true negative serum samples. Twelve of the 55 noncases who self-reported a suspected COVID-19 infection also reported positive rRT-PCR-test results in the questionnaires, despite not being registered in the national registry system. Possible explanations for this discrepancy are that they had received their diagnoses abroad, or that there was a misinterpretation of the questionnaire. Nevertheless, excluding those who had reported being tested positive for SARS-CoV-2 with rRT-PCR among the non-cases, we found 7/312 seropositive samples among the non-cases. Six of these were from County 1 which had the highest surge of COVID-19 during the first months of the pandemic in Sweden. About $9 \%$ of non-cases in County 1 had detectable antibody levels against either the spike or nucleocapsid protein, compared to $2 \%$ 
medRxiv preprint doi: https://doi.org/10.1101/2021.06.16.21258960; this version posted June 18, 2021. The copyright holder for this preprint (which was not certified by peer review) is the author/funder, who has granted medRxiv a license to display the preprint in perpetuity.

All rights reserved. No reuse allowed without permission.

188 in the other two Counties (Table S3). Due to the non-random selection and bias in the sampling 189 algorithm used here, the result is most likely an underestimate of the proportion of undiagnosed 190 cases in the population.

The well-characterized panel of serum samples presented here will be valuable for

192 diagnostic performance and quality assessments of current and new serological assays.

\section{Acknowledgments}

We thank all voluntary participants for donating blood. We also want to thank the health

195 care centres and regional laboratories for blood sampling and serum preparation as well as the 196 SciLifeLab Autoimmunity and Serology profiling facility for analysis of serum samples. Jenny 197 Belin, Carolina Sandman, Jenny Lindahl and Ingela Persson, RISE Research Institutes of Sweden, 198 are acknowledged for setting up the quality management system handling the serum samples, 199 technical assistance and for providing valuable advice on sampling. We are grateful to Karin 200 Tegmark-Wisell, Charlotta Nilsson and Jonas Klingström, Public Health Agency of Sweden, and 201 Magnus Larsson, RISE Research Institute of Sweden, for reading and giving valuable input to the 202 manuscript.

\section{References}

204 1. Cucinotta D, Vanelli M. WHO Declares COVID-19 a Pandemic. Acta Biomed. 2020 Mar 205 19;91(1):157-60.

206 2. Li D, Li J. Immunologic Testing for SARS-CoV-2 Infection from the Antigen

207 Perspective. J Clin Microbiol. 2021 Apr 20;59(5). 
medRxiv preprint doi: https://doi.org/10.1101/2021.06.16.21258960; this version posted June 18, 2021. The copyright holder for this preprint (which was not certified by peer review) is the author/funder, who has granted medRxiv a license to display the preprint in perpetuity.

All rights reserved. No reuse allowed without permission.

208 3. Liu L, Wang P, Nair MS, Yu J, Rapp M, Wang Q, et al. Potent neutralizing antibodies

209 against multiple epitopes on SARS-CoV-2 spike. Nature. 2020 Aug;584(7821):450-6.

210 4. Sherina N, Piralla A, Du L, Wan H, Kumagai-Braesch M, Andrell J, et al. Persistence of

211 SARS-CoV-2-specific B and T cell responses in convalescent COVID-19 patients 6-8 months

212 after the infection. Med (N Y). 2021 Mar 12;2(3):281-95 e4.

213 5. Anand SP, Prevost J, Nayrac M, Beaudoin-Bussieres G, Benlarbi M, Gasser R, et al.

214 Longitudinal analysis of humoral immunity against SARS-CoV-2 Spike in convalescent

215 individuals up to 8 months post-symptom onset. bioRxiv. 2021 Jan 25.

216 6. Abayasingam A, Balachandran H, Agapiou D, Hammoud M, Rodrigo C, Keoshkerian E,

217 et al. Long-term persistence of $\mathrm{RBD}(+)$ memory $\mathrm{B}$ cells encoding neutralizing antibodies in

218 SARS-CoV-2 infection. Cell Rep Med. 2021 Apr 20;2(4):100228.

219 7. den Hartog G, Vos ERA, van den Hoogen LL, van Boven M, Schepp RM, Smits G, et al.

220 Persistence of antibodies to SARS-CoV-2 in relation to symptoms in a nationwide prospective

221 study. Clin Infect Dis. 2021 Feb 24.

222 8. Gudbjartsson DF, Norddahl GL, Melsted P, Gunnarsdottir K, Holm H, Eythorsson E, et

223 al. Humoral Immune Response to SARS-CoV-2 in Iceland. N Engl J Med. 2020 Oct

$224 \quad 29 ; 383(18): 1724-34$.

225 9. Lumley SF, Wei J, O'Donnell D, Stoesser NE, Matthews PC, Howarth A, et al. The

226 duration, dynamics and determinants of SARS-CoV-2 antibody responses in individual

227 healthcare workers. Clin Infect Dis. 2021 Jan 6. 
medRxiv preprint doi: https://doi.org/10.1101/2021.06.16.21258960; this version posted June 18, 2021. The copyright holder for this preprint (which was not certified by peer review) is the author/funder, who has granted medRxiv a license to display the preprint in perpetuity.

All rights reserved. No reuse allowed without permission.

228 10. Dan JM, Mateus J, Kato Y, Hastie KM, Yu ED, Faliti CE, et al. Immunological memory

229 to SARS-CoV-2 assessed for up to 8 months after infection. Science. 2021 Feb 5;371(6529).

230 11. Rudberg AS, Havervall S, Manberg A, Jernbom Falk A, Aguilera K, Ng H, et al. SARS-

231 CoV-2 exposure, symptoms and seroprevalence in healthcare workers in Sweden. Nat Commun.

2322020 Oct 8;11(1):5064.

233 12. Long QX, Tang XJ, Shi QL, Li Q, Deng HJ, Yuan J, et al. Clinical and immunological

234 assessment of asymptomatic SARS-CoV-2 infections. Nat Med. 2020 Aug;26(8):1200-4.

235 13. Wellinghausen N, Plonne D, Voss M, Ivanova R, Frodl R, Deininger S. SARS-CoV-2-

236 IgG response is different in COVID-19 outpatients and asymptomatic contact persons. J Clin

237 Virol. 2020 Sep;130:104542.

238 14. Harris RJ, Whitaker HJ, Andrews NJ, Aiano F, Amin-Chowdhury Z, Flood J, et al.

239 Serological surveillance of SARS-CoV-2: Six-month trends and antibody response in a cohort of

240 public health workers. J Infect. 2021 Mar 22.

241 15. Marklund E, Leach S, Axelsson H, Nystrom K, Norder H, Bemark M, et al. Serum-IgG

242 responses to SARS-CoV-2 after mild and severe COVID-19 infection and analysis of IgG non-

243 responders. PLoS One. 2020;15(10):e0241104.

244 16. Wolf J, Kaiser T, Pehnke S, Nickel O, Lubbert C, Kalbitz S, et al. Differences of SARS-

245 CoV-2 serological test performance between hospitalized and outpatient COVID-19 cases. Clin

246 Chim Acta. 2020 Dec;511:352-9.

247 17. Surkova E, Nikolayevskyy V, Drobniewski F. False-positive COVID-19 results: hidden

248 problems and costs. Lancet Respir Med. 2020 Dec;8(12):1167-8. 
medRxiv preprint doi: https://doi.org/10.1101/2021.06.16.21258960; this version posted June 18, 2021. The copyright holder for this preprint (which was not certified by peer review) is the author/funder, who has granted medRxiv a license to display the preprint in perpetuity.

All rights reserved. No reuse allowed without permission.

249 18. Yahav D, Yelin D, Eckerle I, Eberhardt CS, Wang J, Cao B, et al. Definitions for

250 coronavirus disease 2019 reinfection, relapse and PCR re-positivity. Clin Microbiol Infect. 2021

251 Mar;27(3):315-8.

252 19. Wu F, Liu M, Wang A, Lu L, Wang Q, Gu C, et al. Evaluating the Association of

253 Clinical Characteristics With Neutralizing Antibody Levels in Patients Who Have Recovered

254 From Mild COVID-19 in Shanghai, China. JAMA Intern Med. 2020 Oct 1;180(10):1356-62.

255 20. Sun B, Feng Y, Mo X, Zheng P, Wang Q, Li P, et al. Kinetics of SARS-CoV-2 specific

256 IgM and IgG responses in COVID-19 patients. Emerg Microbes Infect. 2020 Dec;9(1):940-8.

257 21. Li K, Huang B, Wu M, Zhong A, Li L, Cai Y, et al. Dynamic changes in anti-SARS-

258 CoV-2 antibodies during SARS-CoV-2 infection and recovery from COVID-19. Nat Commun.

2592020 Nov 27;11(1):6044.

260 22. Wu J, Liang B, Chen C, Wang H, Fang Y, Shen S, et al. SARS-CoV-2 infection induces

261 sustained humoral immune responses in convalescent patients following symptomatic COVID-

262 19. Nat Commun. 2021 Mar 22;12(1):1813.

263 23. Mahallawi W, Alzahrani M, Alahmadey Z. Durability of the humoral immune response 264 in recovered COVID-19 patients. Saudi J Biol Sci. 2021 Feb 16.

265 24. Schaffner A, Risch L, Weber M, Thiel S, Jungert K, Pichler M, et al. Sustained SARS-

266 CoV-2 nucleocapsid antibody levels in nonsevere COVID-19: a population-based study. Clin

267 Chem Lab Med. 2020 Nov 19;59(2):e49-e51. 
268 25. Khoury DS, Cromer D, Reynaldi A, Schlub TE, Wheatley AK, Juno JA, et al.

269 Neutralizing antibody levels are highly predictive of immune protection from symptomatic

270 SARS-CoV-2 infection. Nat Med. 2021 May 17.

271 26. Gaebler C, Wang Z, Lorenzi JCC, Muecksch F, Finkin S, Tokuyama M, et al. Evolution

272 of antibody immunity to SARS-CoV-2. Nature. 2021 Mar;591(7851):639-44.

273

274 Table 1. Age, gender and self-reported symptoms of patient-cases and non-cases.

\begin{tabular}{llll}
\hline & Patient-cases (\%) & Non-cases (\%) & Total (\%) \\
\hline N & $145(31)$ & $324(69)$ & $469(100)$
\end{tabular}

\section{Gender}

Female

89 (61)

$181(56)$

$270(58)$

Male

56 (39)

$143(44)$

$199(42)$

\section{Age group}

$18-29$

14 (10)

45 (14)

$59(13)$

$30-44$

39 (27)

78 (24)

$117(25)$

45-59

70 (48)

$114(35)$

$184(39)$

$\geq 60$

$22(15)$

87 (27)

$109(23)$

\section{Symptoms of respiratory-tract}

infections during 2020*

Yes

$115(79)$

$127(39)$

$242(52)$ 


$\begin{array}{lll}\mathrm{No} \dagger & 30(21) & 197(61)\end{array}$

\section{Severity of symptoms:}

Mild

Moderate

Severe

No data
$123(85)$

$16(11)$

$5(3.4)$

$1(0.7)$
$52(16)$

$3(0.9)$

$0(0)$

$269(83)$
$175(37)$

$19(4.1)$

$5(1.1)$

$270(58)$

275 * Symptoms of respiratory tract infections and severity of disease were extracted from the 276 questionnaires.

$277 \dagger$ Of those that reported no RTI-symptoms, 29/30 of patient-cases and 12/197 of non-cases, 278 respectively, reported symptoms that they suspected were due to COVID-19.

$279 \$$ The question of severity of symptoms applied only to those who answered "Yes" on the question

280 "Did you have symptoms during 2020 that you know, or suspect were due to COVID-19" (n=144

281 for cases, and $\mathrm{n}=55$ for non-cases $)$. Mild disease was defined as staying at home while being ill,

282 moderate as hospital admission and severe as ICU admission. 
medRxiv preprint doi: https://doi.org/10.1101/2021.06.16.21258960; this version posted June 18, 2021. The copyright holder for this preprint (which was not certified by peer review) is the author/funder, who has granted medRxiv a license to display the preprint in perpetuity.

All rights reserved. No reuse allowed without permission.

289 Table 2. IgG-antibodies detected in serum samples of patient-cases and non-cases.

\begin{tabular}{|c|c|c|c|c|}
\hline $\begin{array}{l}\text { Reactive IgG antibody } \\
\text { against }\end{array}$ & $\begin{array}{l}\text { Patient-cases } \\
(n=145)\end{array}$ & $\%(95 \% \mathrm{CI})$ & $\begin{array}{l}\text { Non-cases } \\
(\mathrm{n}=324)\end{array}$ & $\%(95 \% \mathrm{CI})$ \\
\hline Spike & 140 & $96.6(92.2-98.5)$ & 21 & $6.5(4.3-9.7)$ \\
\hline Nucleocapsid & 138 & $95.2(90.4-97.6)$ & 18 & $5.6(3.6-8.6)$ \\
\hline Spike and Nucleocapsid & 137 & $94.5(89.5-97.2)$ & 14 & $4.3(2.6-7.1)$ \\
\hline None & 4 & $2.8(1.1-6.9)$ & 299 & $92.3(88.9-94.7)$ \\
\hline
\end{tabular}




\section{Figures}

293 Figure 1. Antibody levels against viral spike and nucleocapsid proteins in patient-cases $(n=145)$

294 and non-cases $(\mathrm{n}=324)$, respectively. Boxes include values between the first $(\mathrm{Q} 1)$ and third $(\mathrm{Q} 3)$

295 quartile, whiskers limits shows values within $\mathrm{Q} 1-\mathrm{IQR} \times 1.5$ and $\mathrm{Q} 3+\mathrm{IQR} \times 1.5$. Outliers are defined

296 as values outside the whisker limits and median values are indicated by a line. IQR: Interquartile

297 range.

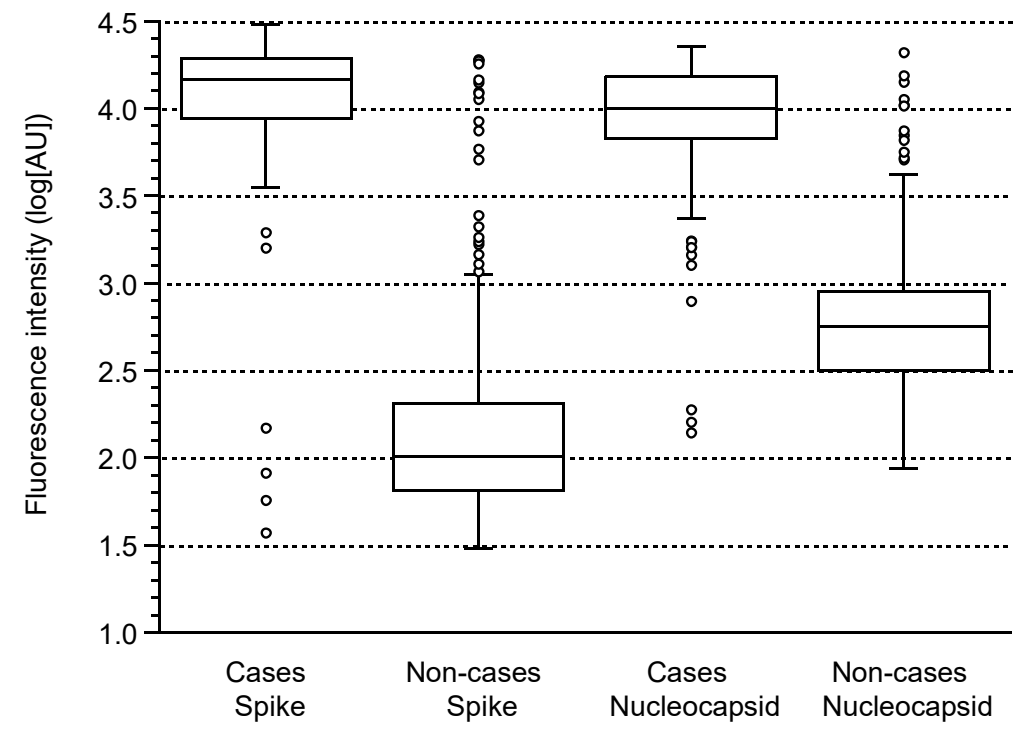

298 
medRxiv preprint doi: https://doi.org/10.1101/2021.06.16.21258960; this version posted June 18, 2021. The copyright holder for this preprint (which was not certified by peer review) is the author/funder, who has granted medRxiv a license to display the preprint in perpetuity. All rights reserved. No reuse allowed without permission.

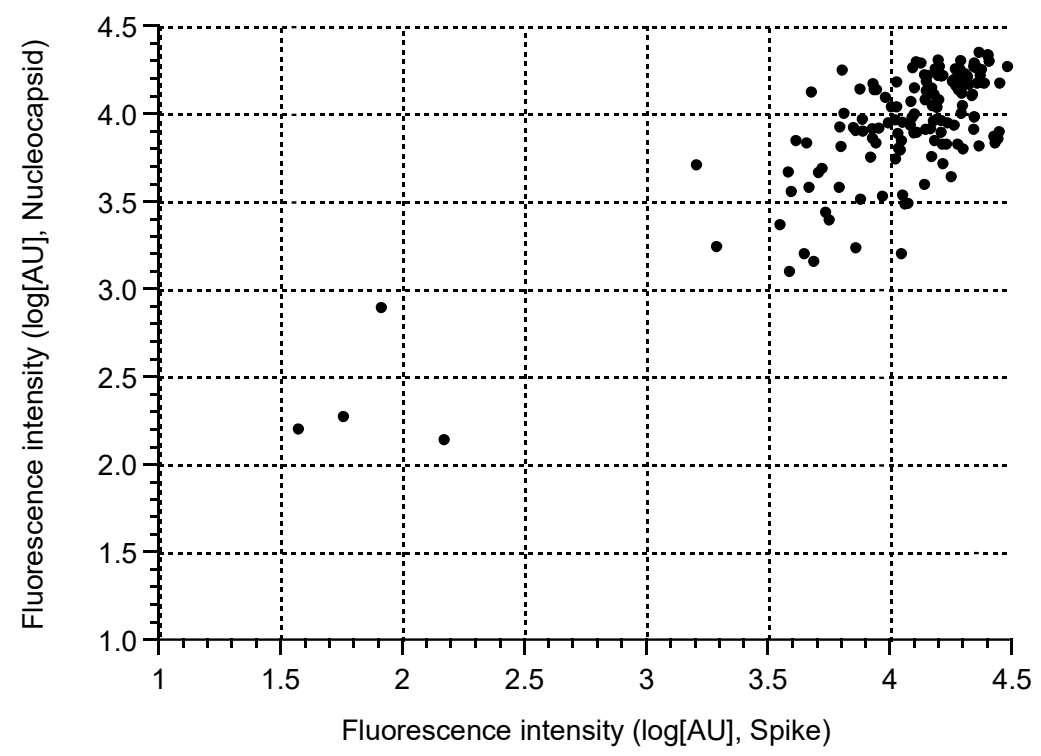


medRxiv preprint doi: https://doi.org/10.1101/2021.06.16.21258960; this version posted June 18, 2021. The copyright holder for this preprint (which was not certified by peer review) is the author/funder, who has granted medRxiv a license to display the preprint in perpetuity.

All rights reserved. No reuse allowed without permission.

315 Figure 3. Antibody levels in patient-cases with mild vs. moderate-severe disease $(\mathrm{n}=120$ vs. $\mathrm{n}=$

31621 , respectively, four outliers removed). For explanation of boxes, see legend to Figure 1.

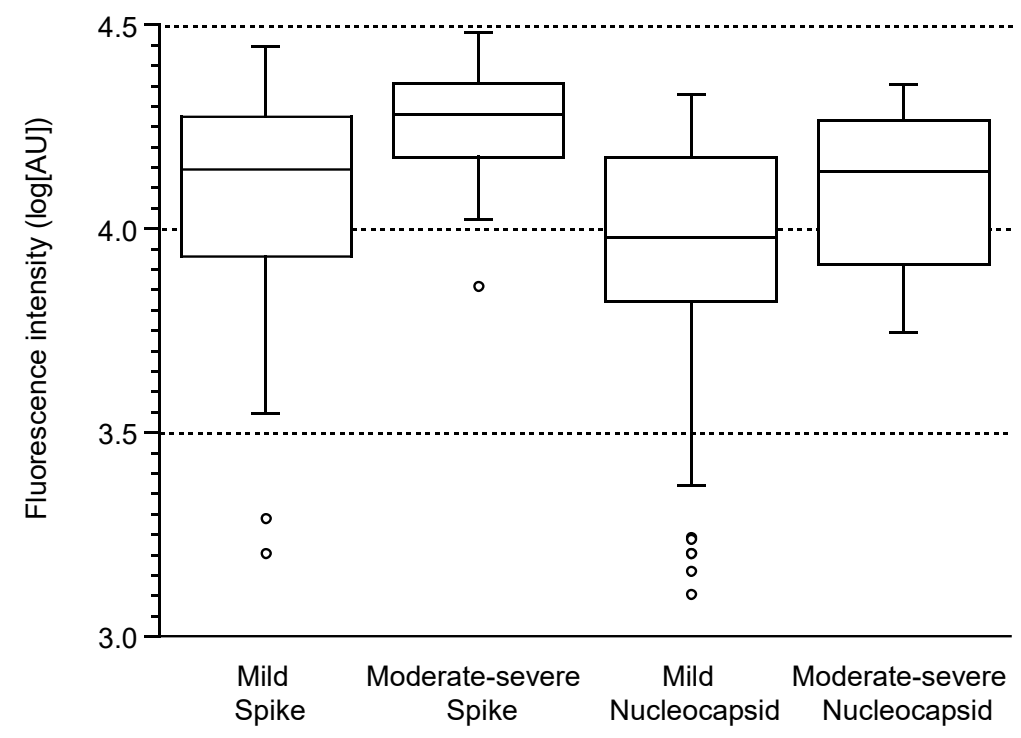

317 
medRxiv preprint doi: https://doi.org/10.1101/2021.06.16.21258960; this version posted June 18, 2021. The copyright holder for this preprint (which was not certified by peer review) is the author/funder, who has granted medRxiv a license to display the preprint in perpetuity. All rights reserved. No reuse allowed without permission.

Figure 4. Correlation of antibody levels among patient-cases and time between disease notification and serum sampling $(\mathrm{n}=141,4$ outliers removed $)$.

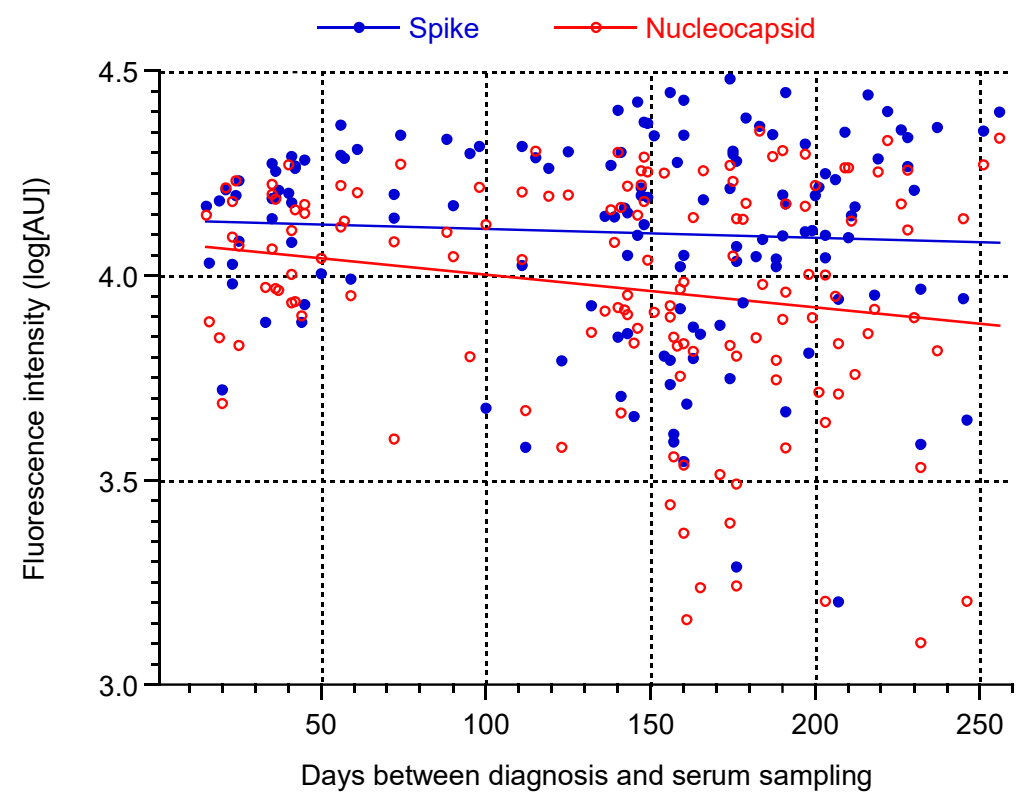

